\title{
Pollen development and fertilization in Arabidopsis is dependent on the MALE GAMETOGENESIS IMPAIRED ANTHERS gene encoding a Type V P-type ATPase
}

\author{
Mia Kyed Jakobsen, ${ }^{1}$ Lisbeth R. Poulsen, ${ }^{1}$ Alexander Schulz, ${ }^{1}$ Pierrette Fleurat-Lessard, ${ }^{3}$ \\ Annette Møller, ${ }^{1}$ Søren Husted, ${ }^{2}$ Morten Schiøtt, ${ }^{1}$ Anna Amtmann, ${ }^{4}$ and Michael G. Palmgren ${ }^{1,5}$ \\ ${ }^{1}$ Department of Plant Biology and ${ }^{2}$ Department of Agricultural Sciences, The Royal Veterinary and Agricultural University, \\ DK-1871 Frederiksberg C, Denmark; ${ }^{3}$ Laboratoire de Physiologie et Biochimie Végétales, Unite de Recherche Associée au \\ Centre National de la Recherche Scientifique 574, Universite de Poitiers, 86000 Poitiers, France; ${ }^{4}$ Plant Science Group, \\ Institute of Biomedical and Life Sciences, University of Glasgow, Glasgow G12 8QQ, United Kingdom
}

In flowering plants, development of the haploid male gametophytes (pollen grains) takes place in a specialized structure called the anther. Successful pollen development, and thus reproduction, requires high secretory activity in both anther tissues and pollen. In this paper, we describe a novel member of the eukaryotic type $\mathrm{V}$ subfamily $\left(\mathrm{P}_{5}\right)$ of P-type ATPase cation pumps, the MALE GAMETOGENESIS IMPAIRED ANTHERS (MIA) gene. MIA protein is highly abundant in the endoplasmic reticulum and small vesicles of developing pollen grains and tapetum cells. T-DNA insertional mutants of MIA suffer from imbalances in cation homeostasis and exhibit a severe reduction in fertility. Mutant microspores fail to separate from tetrads and pollen grains are fragile with an abnormal morphology and altered cell wall structure. Disruption of MIA affects expression of genes essential for secretion as well as a high number of genes encoding cell wall proteins and membrane transporters. MIA functionally complements a mutant in the $P_{5}$ ATPase homolog SPF1 from Saccharomyces cerevisiae, suggesting a common function for $P_{5}$ ATPases in single and multicellular organisms. Our results suggest that MIA is required in the secretory pathway for proper secretion of vesicle cargo to the plasma membrane.

[Keywords: P-type ATPase; secretory pathway; pollen; male gametogenesis]

Supplemental material is available at http://www.genesdev.org.

Received June 27, 2005; revised version accepted September 5, 2005.

The life cycle of flowering plants alternates between a haploid organism, the gametophyte, and a diploid organism, the sporophyte. Plants have male and female gametophytes, both of which are multicellular. The male gametophyte, the pollen grain, is, at the mature stage, a three-cell organism consisting of a vegetative cell and two sperm cells. Pollen development starts inside the anther, which is a specialized structure of the flower, with the meiotic divisions of the microsporocytes to form a tetrad of haploid spores (for review, see McCormick 2004). The microspores are embedded in callose, and release from the tetrad requires degrading enzymes secreted by the somatic tapetum layer (Stieglitz 1977;

${ }^{5}$ Corresponding author.

E-MAIL palmgren@kvl.dk; FAX 45-3528-3365.

Article and publication are at http://www.genesdev.org/cgi/doi/10.1101/ gad.357305.
Rhee and Somerville 1998). Both the sporophytic tapetal layer and the developing gametophyte produce components for the subsequent biosynthesis of the complex wall of the pollen grain that consists of two distinct layers, the inner intine and the outer exine layer (for review, see Scott et al. 2004).

Recent genome-wide analysis of the male gametophyte transcriptome in Arabidopsis suggests that pollen contain a transcriptome with a unique composition. Of the estimated 3500 genes expressed during pollen development $>1400$ may be preferentially or specifically expressed in pollen (Honys and Twell 2003). Few of these genes have been characterized functionally, one reason being that reduced transmission of the mutant allele through the haploid male gametophyte renders mutant analysis difficult. A number of gametophytic mutants have been described phenotypically (e.g., see Chen and 
McCormick 1996; Sari-Gorla et al. 1997; Park et al. 1998; Procissi et al. 2001; Lalanne and Twell 2002). However, only a few have been characterized with respect to the genes responsible for the observed defects.

In this paper, we describe the single member of the $\mathrm{P}_{5}$ ATPase subfamily of cation pumps in Arabidopsis. $\mathrm{P}_{5}$ ATPases are ubiquitous in eukaryotic organisms but are absent from the prokaryotic genomes sequenced so far. Five genes encoding $\mathrm{P}_{5}$ ATPases are present in each of the genomes of Homo sapiens, Mus musculus, and Rattus norvegicus; four in Caenorhabditis elegans; one in Drosophila melanogaster; three in Schizosaccharomyces pombe; and two in Saccharomyces cerevisiae (The P-type ATPase database, http://www.patbase.kvl.dk). In yeast, Spflp may be involved in protein biogenesis and modification at early stages of the secretory pathway (Suzuki and Shimma 1999; Ng et al. 2000; Vashist et al. 2002). In multicellular organisms, no $P_{5}$ ATPase has been described so far.

Here we show that plants homozygous for male gametogenesis impaired anthers (mia) mutations produce fragile pollen grains that fail to dissociate from tetrads. High levels of MIA protein are present in the endoplasmic reticulum (ER) and secretory vesicles of the tapetum and developing pollen grains. A large number of genes belonging to a few well-defined functional groups are changed in the anthers of mia mutants, as revealed by expression profiling. Taken together, our results suggest that MIA plays an important role in pollen development in Arabidopsis through its impact on protein secretion and transport processes.

\section{Results}

Identification of a $P_{5}$ ATPase in Arabidopsis

The P-type ATPase superfamily constitutes a large group of homologous ion transporters present in all phyla from bacteria to man. The genes are divided into five evolutionarily related subfamilies, designated $\mathrm{P}_{1}$ to $\mathrm{P}_{5}$ (or Type I to Type V), which group according to substrate specificities. $\mathrm{P}_{5}$ ATPases were first demonstrated in silico (Axelsen and Palmgren 1998) and, although they are absent from eubacteria and archaea, have now been identified in all fully sequenced eukaryotic genomes (Axelsen and Palmgren 2001), suggesting an important function for these putative ion transporters in higher organisms.

The Arabidopsis Genome Initiative (2000) revealed a single $\mathrm{P}_{5}$ ATPase member in Arabidopsis, encoded by GenBank accession number At5g23630 (Axelsen and Palmgren 2001). Due to the male gametogenesis impaired anthers phenotype of knockout mutants in this gene (see below), we named the gene MIA. We cloned the cDNA for MIA by polymerase chain reaction (PCR) using a cDNA library prepared from 3-d-old hypocotyls as template. The cDNA encodes an 1179-amino-acid polypeptide with a predicted molecular mass of $130 \mathrm{kDa}$ (Fig. 1A). The encoded MIA protein contains the P-type ATPase signature motif DKTGTLT (Fig. 1A), including
$\mathbf{A}$

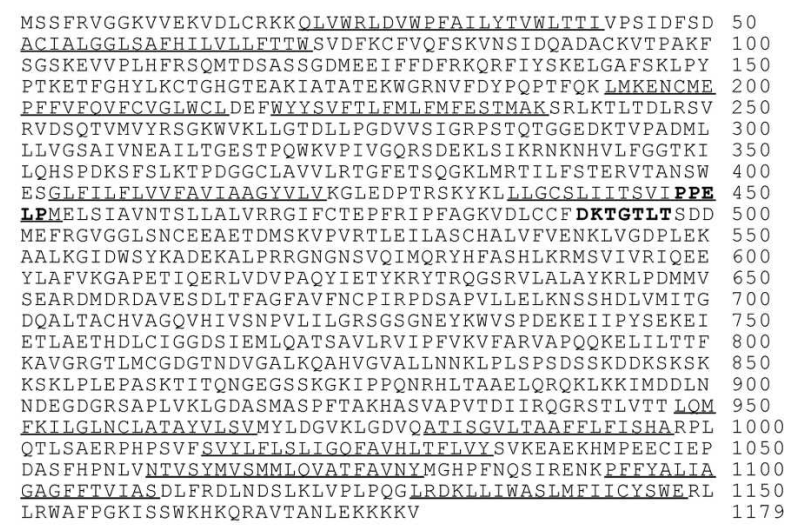

B

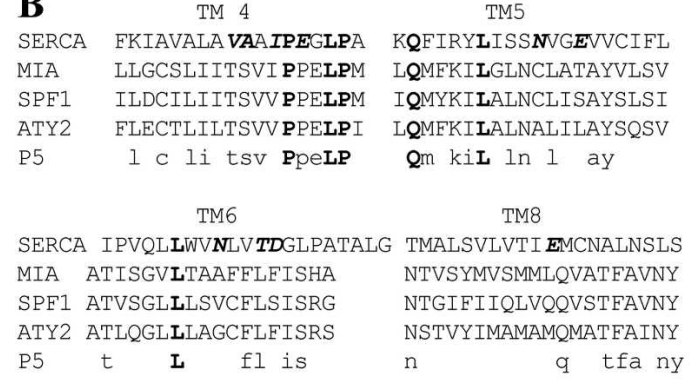

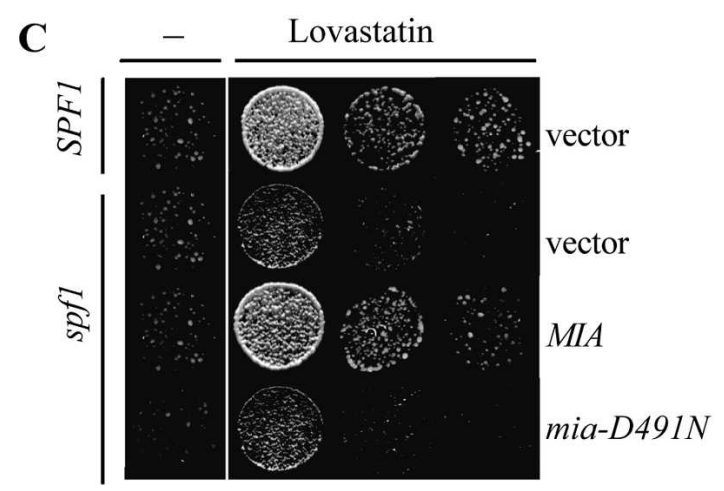

Figure 1. MIA encodes a $\mathrm{P}_{5}$-type ATPase, which functionally complements a mutation in the S. cerevisiae SPF1. (A) Amino acid sequence of MIA. The P-type and $\mathrm{P}_{5}$ ATPase signature sequences are shown in bold. Putative transmembrane-spanning helices are underlined. $(B)$ Alignment of transmembrane domains involved in ion binding in SERCA1 with the corresponding domains in MIA, Spf1p, and ATY2. Amino acid residues involved in ion binding in SERCA1 are shown in italics. Conserved amino acids are shown in bold. Residues conserved in in all three $\mathrm{P}_{5}$ ATPases are shown in the consensus line below the alignment. $(C)$ Functional complementation of a mutation in the yeast secretory pathway ATPase SPF1. Growth of wild-type yeast transformed with pYES2.0 (vector control), and spf1 transformed with vector pYES2.0, MIA, or mia-D491N. The plates contained minimal medium $\pm 200 \mu$ g lovastatin.

the aspartate residue phosphorylated during the reaction cycle, as well as the PPxxP motif, in the preceding putative transmembrane segment (Fig. 1A,B), which is present in all $\mathrm{P}_{5}$ ATPases (Axelsen and Palmgren 1998). 
MIA is most similar to the human $\mathrm{P}_{5}$ ATPase ATY2 ( $44 \%$ identity) and to Spf $1 p$ from S. cerevisiae (41\% identity). Residues that in the P-type $\mathrm{Ca}^{2+}$ pump SERCA1 have been shown to be implicated in $\mathrm{Ca}^{2+}$ coordination are not conserved in MIA (Fig. 1B).

\section{MIA complements a mutation in yeast SPF1}

To study whether MIA function is conserved across species boundaries we tested whether MIA could rescue the phenotype resulting from a mutation in the related yeast SPF1 gene (Cronin et al. 2000). The spf1 mutant is defective in regulating controlled hydroxymethylglutarylcoenzyme A reductase (HMGR) degradation and is sensitive to lovastatin (Cronin et al. 2000), an inhibitor of the ER resident membrane protein HMGR. Introduction of MIA into spf1 restored growth on medium containing lovastatin (Fig. 1C), indicating that MIA and Spflp are functionally homologous. We also tested whether a presumably inactive mutant of MIA would influence yeast growth. For this purpose we substituted the aspartate residue in the P-type ATPase signature motif DKTGTLT (Fig. 1A; Asp-491 in MIA) with an asparagine residue. As expected, the D491N mutant was not able to rescue growth of spf1 mutant cells (Fig. 1C).

\section{Intracellular localization of MIA in Arabidopsis}

To study the protein localization of MIA in plants, antiserum was raised against synthetic peptides corresponding to a unique part of MIA (amino acid residues 850-864 in the end of the predicted large cytoplasmic loop). The antibody recognized a single band of $\sim 130 \mathrm{kDa}$ corresponding to the predicted size of MIA on protein blots (data not shown). Anti-MIA antibody that had been saturated with the peptide epitope prior to incubation on Western blots did not produce any bands, suggesting that the antibody is specific to MIA (data not shown).

Despite the fact that our RT-PCR experiments (data not shown) and information from databases (http:// mpss.dbi.udel.edu and http://www.weigelworld.org/ resources/microarray/AtGenExpress) suggested the presence of MIA transcripts in all major plant organs, it proved difficult to unequivocally identify MIA protein by immunolocalization in roots and leaf material of Arabidopsis. This could be due to low levels of protein being present or to interfering fluorescence; for example, from chlorophyll in leaves. However, high levels of immunofluorescence were observed in anthers at different stages of development, specifically the tapetal cell layer and developing pollen grains (data not shown). In these cells, the intracellular localization of the MIA protein was examined using electron microscopy of ultrathin anther sections (Fig. 2). Immunogold labeling (arrows) of MIA was most prominent at the ER (open arrows) of developing pollen grains (Fig. 2A,C,D). MIA protein was also detected in the ER in tapetal cells (Fig. 2E,F) and, at lower levels, in the parenchyma cells next to the tapetum (data not shown). In addition, labeling of small
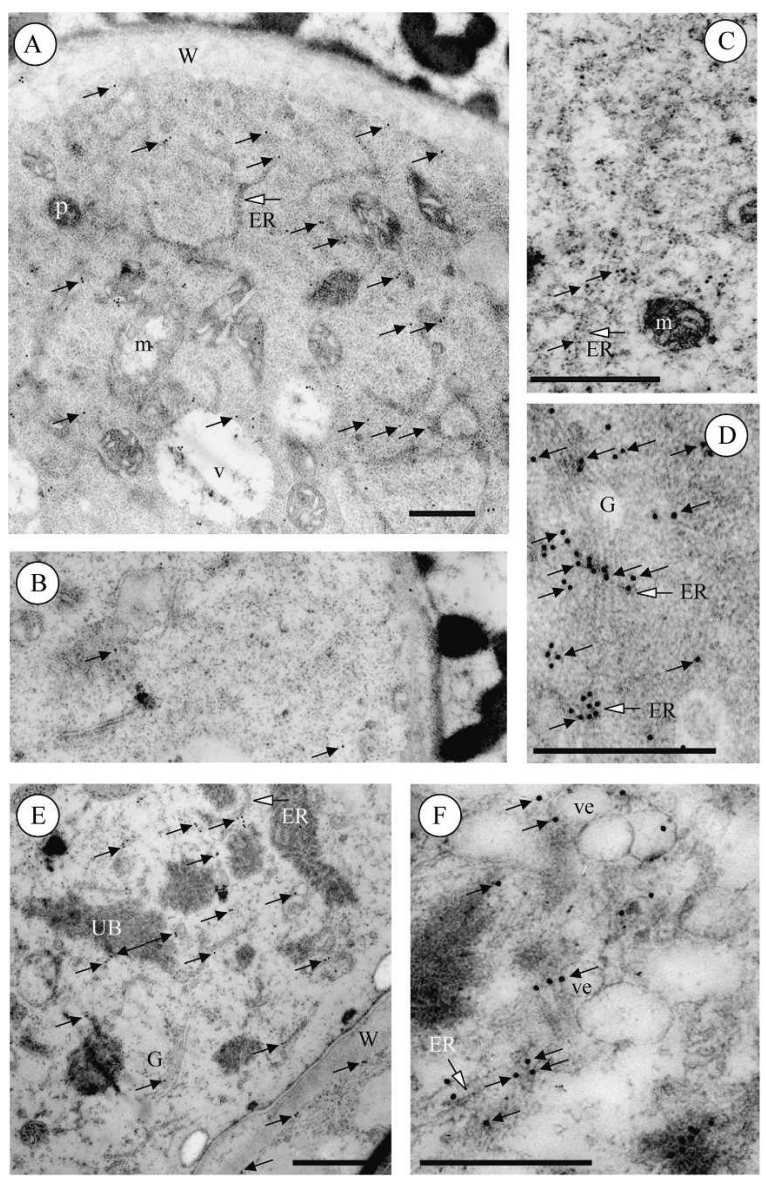

Figure 2. Intracellular localization of MIA in pollen and tapetum tissues. (A) Labeling (arrows) in cross-sections of pollen grain in Arabidopsis thaliana. Sites recognized mainly in the ER (open arrows). (B) Control pollen, antibody saturated with the purified protein, gives rise to weak background only. $(C)$ Labeling in the ER area. $(D)$ Detail of labeling in the ER. $(E)$ Immuno-decoration of tapetal cells. $(F)$ Detail of tapetum decoration in $E$ showing labeling of vesicles. (G) Golgi, $(\mathrm{m})$ mitochondria, (p) plastid, (v) vacuole, (ve) vesicle, (w) wall, (UB) ubisch bodies. Bar, $1 \mu \mathrm{m}$.

vesicles (ve) was observed (Fig. 2F). Antibody saturated with the recombinant epitope was used as a control and gave rise to background noise only (Fig. 2B). These results suggest that MIA protein localizes to the ER and small, probably ER-derived vesicles in the male reproductive tissues.

\section{Isolation of MIA insertion mutants}

A reverse genetic approach based on the isolation of $\mathrm{T}$ DNA insertion mutants was employed to reveal the physiological function of the MIA gene in Arabidopsis. Two different mutants lines, mia-1 and mia-2, were identified by screening a T-DNA-tagged mutant population (Weigel et al. 2000). The T-DNA left border-flanking regions of the knockout alleles were amplified and sequenced to determine the insertion site and the structure of the knockout alleles. The mia-1 allele carries a 


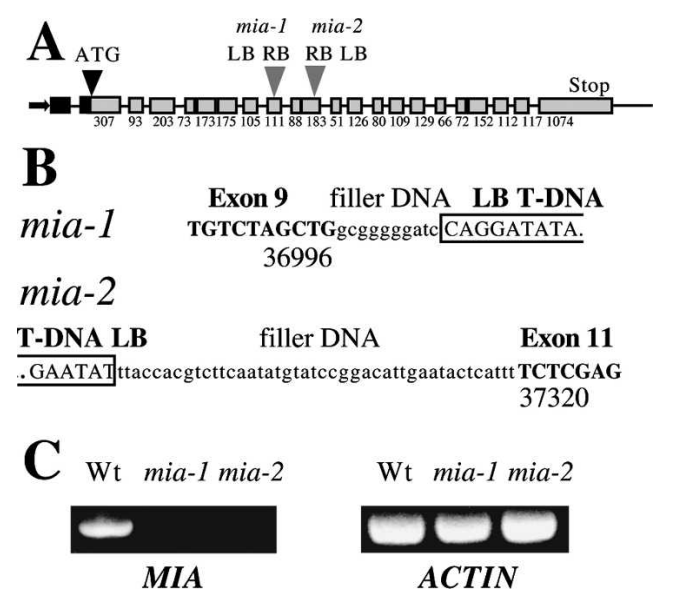

Figure 3. Genomic structure of mia T-DNA insertion mutants. (A) Genomic organization of the MIA gene based on the cloned cDNA sequence and the corresponding genomic sequence from BAC MQM1.11. The promoter is shown as an arrow, the $5^{\prime}$-end untranslated region as a black box, and exons and introns are presented as dark and light shaded boxes, respectively. Sizes of exons are given below the corresponding boxes. The T-DNA insertion sites and the orientation of the inserts are indicated by triangles. T-DNA inserts and exons are not drawn to scale. $(B)$ T-DNA flanking regions in mia-1 and mia-2. The MIA sequence is shown in bold, filler DNA is shown in standard letters, and the T-DNA LB sequence is boxed. $(C)$ RT-PCR analysis of MIA and as control, ACTIN 3, expression in wild-type, mia-1, and mia-2 plants.

T-DNA insertion in the ninth exon and has an intact LB integration site (Fig. 3A,B). As often observed in T-DNA mutants (Krysan et al. 2002), 10 bases of filler DNA had accompanied the T-DNA and was inserted between the T-DNA and the MIA genomic DNA. In the mia-2 allele the T-DNA interrupts the 11th exon of the gene. The mia-2 allele has an intact T-DNA LB integration site and 43 bases of filler DNA. The T-DNA right border seems to be truncated in both lines, as PCR with different primer pairs annealing to the RB and gene-specific sequences downstream of the right border resulted in no amplification. However, using two gene-specific primers, it was possible to amplify MIA sequences next to the T-DNA RB in both lines (data not shown), suggesting that no neighboring genes have been deleted in the mia mutants.

The expression of MIA mRNA in the two knockout lines was examined by reverse transcription PCR. We were able to detect a transcript in template mRNA prepared from wild-type leaf tissue but not in mRNA isolated from mia-1 and mia-2 mutant plants (Fig. 3C). Control ACTIN template was detected in all three lines. Homozygosity of the mutant lines was confirmed by analyzing by PCR using genomic DNA isolated from 12 individual offspring of selfed homozygous mia-1 and mia-2 plants. While the knockout alleles could be amplified from all 12 individuals, no products were generated in PCR reactions using primers amplifying the full MIA gene (data not shown).
Male fertility is severely reduced in mia mutants

To determine the phenotypic effect of the mia mutations, homozygous mia-1 and mia-2 plants were grown in the greenhouse or a growth chamber along with wildtype and heterozygous MIA/mia plants. This analysis revealed that at the transition from the vegetative to the reproductive stages, subtle differences between wildtype and mutant plants became visible. Thus, mutant rosette leaves were shorter than wild-type rosette leaves (Fig. 4A,B) and even at maturity leaves never reached the full size of the wild type (data not shown). Furthermore, mutant plants exhibited delayed transition from the vegetative to reproductive phase. Typically for sterile plants senescence was delayed in the mutants so that flowering continued for $>2$ wk after wild-type plants had wilted.
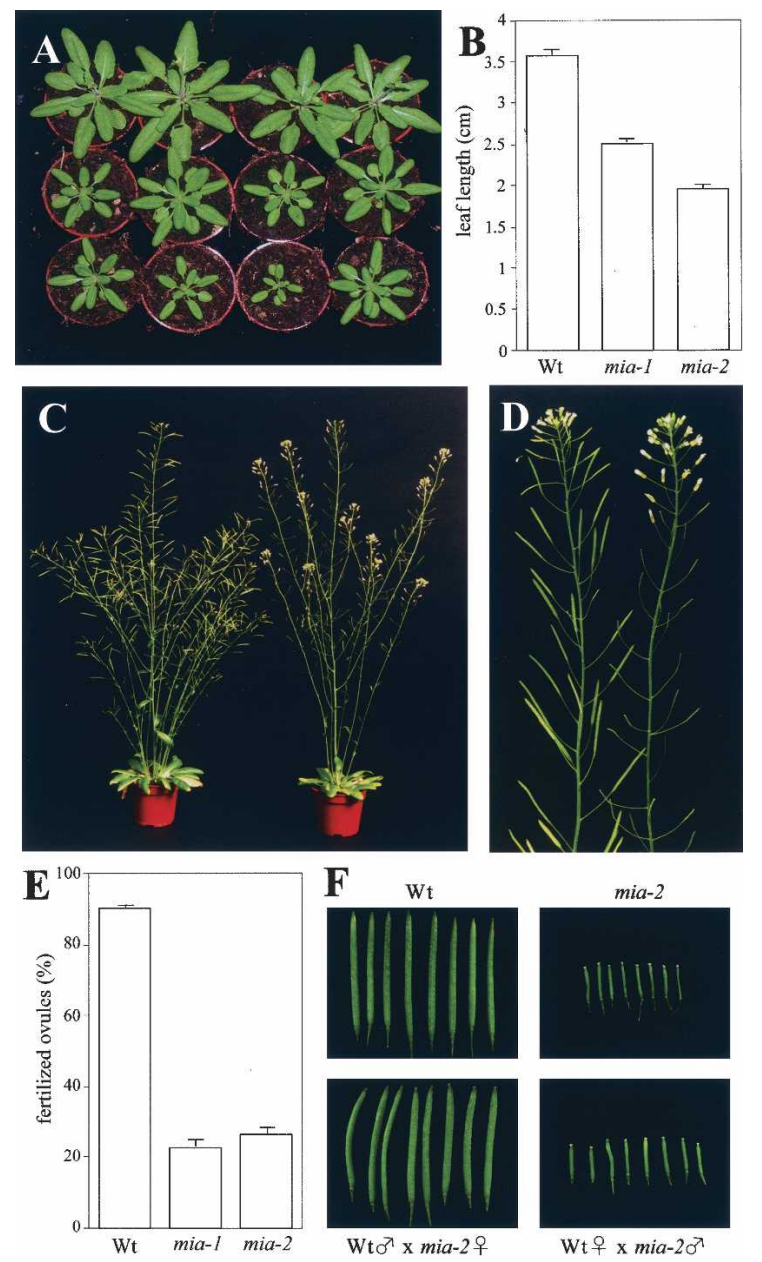

Figure 4. Phenotypes of mia mutant plants. (A) Comparison of rosettes from wild-type (top row), mia-1 (middle row), and mia-2 (bottom row). (B) Rosette leaf length in the wild type and mutants. $(C)$ Comparison of mature wild-type (left) and mia-2 (right) plants. $(D)$ Close-up of stems from wild-type (left) with normal seed pods and mia-2 mutant plants (right) with small seed pods. $(E)$ Percent fertilized ovules in wild-type and mutant plants. (F) Seed pods from wild-type and mia-2 plants and from reciprocal crosses between wild-type and mia-2 demonstrate that the male fertility of mia-2 plants is compromised. 
Overall, the two mia alleles showed phenotypes very similar to each other, consistent with the prediction that both T-DNA insertions would result in null alleles.

Besides the slightly reduced stature, homozygous mutant plants had markedly reduced sizes of their seed pods (Fig. 4C,D). In contrast, heterozygous plants harboring either mutant allele produced seed pods indistinguishable from those of wild-type plants (data not shown). We compared the number of infertile to fertile ovules and found that only $23 \%$ of the ovules in mia-1 and $26 \%$ in mia-2 were fertilized as compared with $92 \%$ in the wild type (Fig. 4E), indicating a markedly reduced fertility in both mutants. The seed set of the mutant was not evenly distributed along the inflorescence axis. Most seed pods produced no seeds, but occasionally seed pods with up to 30 seeds were formed; by comparison, the wild-type plants produced an average of 48 seeds per seed pod $(n=132)$. These mutant seeds were not a result of crosspollination, as MIA transcripts could not be detected by PCR amplification on the progeny from seed-rich mia seed pods $(n=40$; data not shown). The average seed yield per seed pod in the 20 first seed pods formed in the mia-2 mutant was $<2 \%$ of the wild type with a comparable reduction observed for mia-1 (data not shown).

To determine the nature of the sterility we performed reciprocal crosses between wild-type and mutant plants. It was possible to fertilize the knockout mutant using wild-type anthers, whereas pollination of wild-type flowers with mia anthers did not result in seed production (Fig. 4F). This result indicated that the function of the female organs was not compromised in the mutant flowers.

At a later stage of this work we identified in the SALK collection of T-DNA insertion mutants (Alonso et al. 2003) two additional mia alleles (mia-3 and mia-4 in lines SALK 077682 and SALK 052575, respectively). These mutant plants show a phenotype similar to that of mia-1 and mia-2 (data not shown). This suggests that the mutant phenotype is not caused by properties of the T-DNA insert, as two different plasmids were used for mutagenesis of the SALK and Basta populations, respectively (Weigel et al. 2000; Alonso et al. 2003).

mia mutants produce pollen grains that are not released and fail to germinate in vitro

A characteristic feature of mia mutant plants was that, albeit pollen grains were visible in open anther locules, they were not apparent on mature stigmas of mutant plants (Fig. 5A,B). We studied the release of pollen from mutant mia anthers by placing whole mature anthers from wild-type and mutant plants with the open anther locules facing down on top of a water droplet. Pollen release was subsequently examined under a light microscope. In mutant anthers, pollen was released from only one of the 37 anthers tested, whereas pollen was released from all of the 35 wild-type anthers tested (Fig. 5C,D). Interestingly, pollen released from mutant anthers appeared as pollen tetrads (Fig. 5D, arrowhead). In vitro pollen germination tests carried out with whole anthers

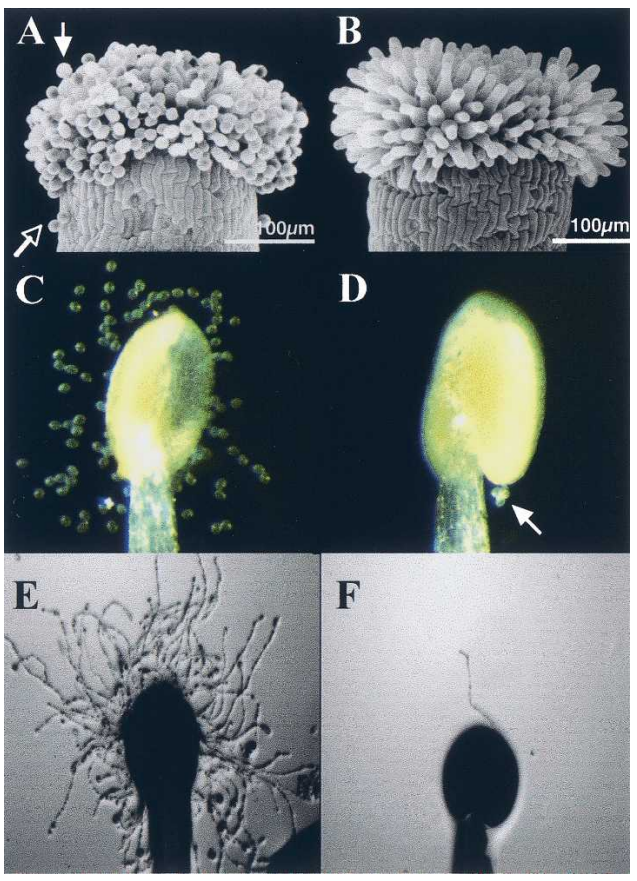

Figure 5. Pollen release and in vitro germination are defects in mia mutant plants. (A) The surface of the female part of the flower is covered with pollen grains in wild-type plants. (B) No pollen grains are visible on the surface of the female organ in mia-1 mutants. Light microscopy photos of pollen release from wild type showing released pollen grains $(C)$ and mia-2 with only one tetrad pollen visible ( $D$, arrow). Phase contrast light micrographs of in vitro pollen germination from wild type with numerous germinating pollen tubes $(E)$ and mia-2 flowers with only one germinating pollen tube $(F)$. Images are representative for both mia-1 and mia-2.

showed that, in contrast to wild-type grains, pollen from the mia mutants exhibited very poor germination and only one germinating pollen tube was observed from the 30 anthers examined (Fig. 5E,F). These data strongly indicate that MIA is essential for pollen release and subsequent germination.

\section{Pollen of mia mutants is fragile and remains associated in tetrads}

Examination of mia mutant anthers by electron microscopy revealed that pollen grains were attached in tetrahedrons of four individual grains and, in addition, exhibited a deformed morphology (Fig. 6D-G). In some anthers, pollen grains had collapsed completely (Fig. 6E). Exine fusions were observed between the pollen grains within each tetrad (Fig. 6F). The mutant pollen grains frequently had a layer of material deposited on the surface (Fig. 6G) resembling callosic or pollen mother cell wall remnants, which could suggest that either of these transient walls was not sufficiently degraded during pollen development to allow microspore release. The layer was also detectable by transmission electron microscopy as an electron-dense material present between the indi- 

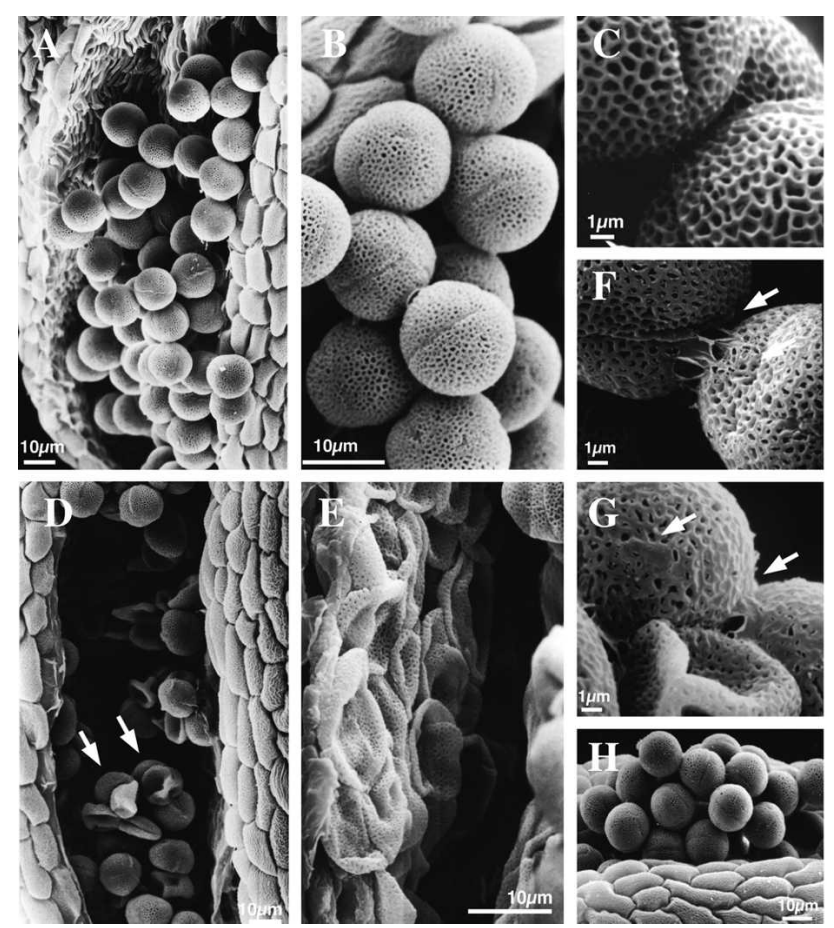

Figure 6. mia mutant pollen is deformed and arranged in tetrads. Scanning electron micrographs of mature pollen grains from wild-type $(A-C)$ and mia-1 insertion mutants $(D-G)$. (D) A substantial proportion of mia-1 pollen grains are collapsed. Arrows point to pollen tetrad. $(E)$ mia-1 anther locule with completely collapsed pollen grains. $(F)$ Magnification of mia-1 pollen grains. Arrow points to exine walls fusing two pollen grains. $(G)$ A layer of material, possibly pollen mother cell wall remnant, is deposited onto mia-1 pollen grains. $(H)$ Pollen grains from heterozygous $M I A / m i a-1$ plant have wild-type morphology. Photos are representative for both mia-1 and mia-2.

vidual pollen grains of each tetrad and also between pollen grains and cells of the anther locule (Fig. 7C). This indicates that the material in question is not callosic, which would appear electron translucent. The transmission electron microscopy furthermore revealed that the apertures, which are well-defined regions of the pollen surface where the wall is reduced or absent to allow pollen germination (Fig. 7A), were extended on the mutant pollen (Fig. 7B,C). In mutant pollen, the plasma membrane was often withdrawn from the cell wall (Fig. 7C), which could reflect improper cellular osmotic homeostasis. Occasionally, pollen grains showed no defined structure in the transmission electron microscope, as they were completely distorted (Fig. 7D).

To answer the question of whether the collapsed tetrad nature of the pollen grains was caused by defects in the somatic or gametophytic contribution to pollen development, we examined the pollen grains of selfed heterozygous plants. Pollen grains from the heterozygous plants were uniform in morphology and appeared indistinguishable from wild-type pollen grains, as revealed in Figure $6 \mathrm{H}$. This indicates that the tetrad phenotype of the pollen grains was caused by sporophytic defects in the mutants. However, this does not rule out an important role for MIA in the gametophyte as well. The competitiveness of pollen carrying one of the mutant mia alleles seems to be affected since, in the progeny of selfed heterozygous plants, fewer seeds homozygous for the mutant alleles than expected from Mendelian inheritance could be recovered (6 out of 99 [i.e., 6\% for mia-1], and 4 out of 49 [i.e., $8 \%$ for mia-2]). The possibility that the mutation affects female fertility can be excluded because pollination of a homozygous mia stigma with wild-type pollen grains resulted in normal seed production. Thus, from the frequency of the homozygous mutant plants, the probability of fertilization by a mutant pollen grain is inferred to be 0.12 (i.e., $0.06 \times 2$ ) for mia-1 and 0.16 (i.e., $0.08 \times 2$ ) for mia-2 in competition with a wild-type pollen grain for which the probability of fertilization would be $0.88(1-0.12)$ or $0.84(1-0.16)$, respectively. To provide further evidence that the disruption of MIA compromises pollen competitiveness in fertilization, we pollinated wild-type plants with pollen grains from mia-1 or mia-2 and subsequently determined the proportion of the progeny resistant to the herbicide BASTA. Data from six separate experiments showed that male transmission of the mutant alleles was reduced to

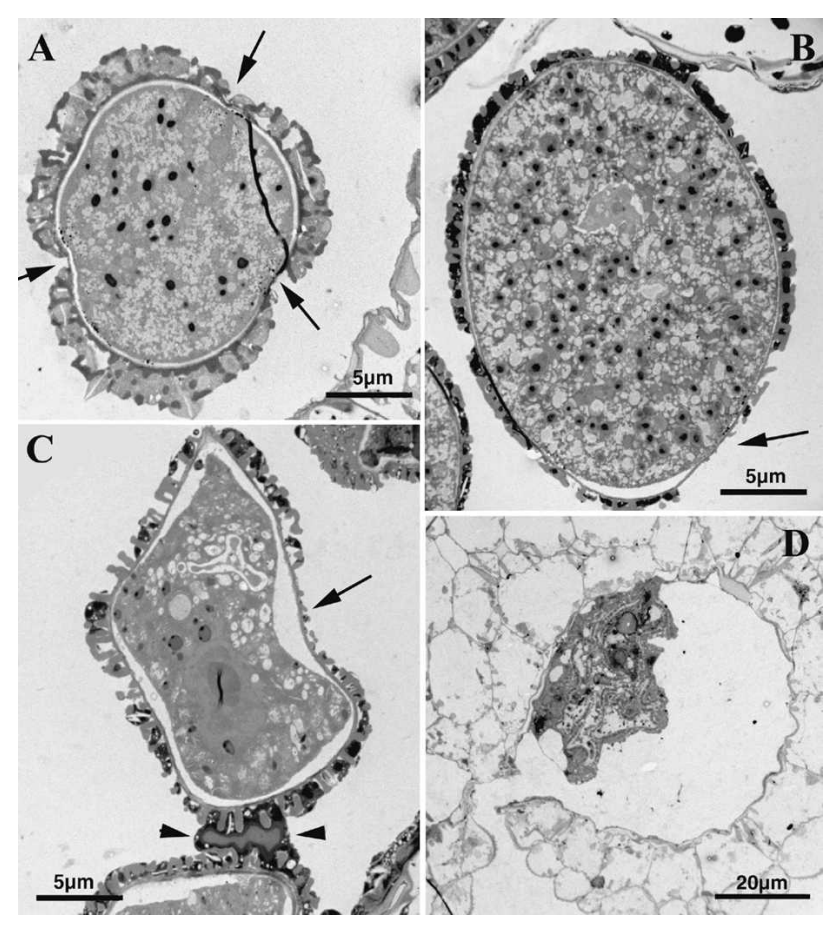

Figure 7. Transmission electron microscopy of wild-type and mia mutant pollen grains. (A) Wild-type pollen grain with dense cytoplasm, well-developed walls, and small apertures (arrows). $(B-D)$ mia mutant pollen grains show extended aperture regions where the exine is reduced in thickness (arrows). Electron-dense material occurs between baculae of the pollen grain walls. $(C)$ Mutant pollen grain showing indications of plasmolysis. An electron-dense material attaches two pollen grains (arrowheads). (D) Pollen sack with completely distorted pollen grain. 
$16 \%$ (mia-1) and $21 \%$ (mia-2) of wild type (Table 1 ). Thus, MIA functions directly in the gametophytic pollen grain, and deletion compromises pollen competitiveness in fertilization.

Disruption of MIA leads to changes in expression of functional groups of genes related to protein secretion, protein folding, and solute transport

To draw a comprehensive picture of the transcriptional changes resulting from disruption of the MIA gene, we carried out full genome microarray analysis of wild-type and mia mutants anthers transcriptome using Affymetrix chips. RNA was prepared from mutant and wild-type anthers collected from flowers at stages 10-12 (Smyth et al. 1990) where the microspores are released from the microspore tetrads inside the anther locules and start to generate exines. To average biological variation, anthers were harvested from 80 different wild-type, mia-1, and mia-2 plants, respectively, which had been grown under identical conditions.

Mutant and wild-type anthers displayed large differences in gene expression. More than 1000 genes showed a difference in expression level of more than threefold between mutants and the wild type. By contrast, $<20$ genes were differentially (more than threefold) expressed between the two mutant lines. Furthermore, we found a strong agreement between the lists of differentially expressed genes of the two mutants with respect to the wild type. Genes that are most strongly affected by the mutation are shown in Tables 2 and 3 (extended lists and raw data are provided as Supplemental Material). The tables include all genes that appear in the top 50 of the ranked fold-change lists for at least one mutant and in the top 100 for the other mutant. The majority of the 50 most strongly regulated genes from each mutant fulfilled these criteria. Fold-changes and ranking of the individual genes are given for both mutants. The fact that two independent mutants show highly similar expression changes when compared with the wild type suggests that the observed changes are indeed directly related to the mutation of MIA.

In both mutants $M I A$ was on top of the list of downregulated genes (Table 2), confirming efficient disruption of its transcription by the mutations. Other genes displaying decreased expression as a consequence of the $M I A$ deletion can be related to the secretory pathway (SEC14, members of the EXO70 family, syntaxins), the cell wall (pectinesterases, expansins, cellulase synthases), and signalling (kinases) (Table 2; Supplemental Material). Some of these functional groups were also identified by the iterative Group Analysis (iGA); for example, calcium-dependent protein kinases (minimum $p$ value $\left.1.6 \times 10^{-10}\right)$, pectinesterases $\left(3.3 \times 10^{-6}\right)$, and cell wall modification $\left(1.8 \times 10^{-4}\right)$.

The list of strongly up-regulated genes (Table 3) includes an unusually high number of transporters, in particular sugar, amino acid, and metal transporters as well as ATPases (plasma membrane $\mathrm{H}^{+}$and $\mathrm{Ca}^{2+}$ pumps and vacuolar $\mathrm{H}^{+}$pump). This observation was statistically supported by iGA, which identified genes representing monosaccharide transporters $\left(3.4 \times 10^{-9}\right)$, organic solute cotransporters $\left(5 \times 10^{-9}\right)$, inorganic solute cotransporters $\left(6.1 \times 10^{-6}\right)$, primary pumps $\left(2.3 \times 10^{-4}\right)$, and proteins with calcium ion storage activity $\left(3.1 \times 10^{-4}\right)$ as differentially expressed. Other functional groups up-regulated in the mutants are heat shock proteins $\left(1.8 \times 10^{-4}\right)$ and ribosomal proteins $\left(8.8 \times 10^{-5}\right)$. A subset of genes representing the type II protein secretion system was also significantly more highly expressed in the mutants than in the wild type $\left(8.4 \times 10^{-5}\right)$.

We conclude that deletion of $M I A$ leads to large changes in gene expression, which affects a small number of well-defined functional groups. The results point to important cellular functions of MIA related to transport, secretion, and protein folding.

\section{MIA regulates cation homeostasis}

Because the microarray analysis suggested that the expression of a number of ion transporters was changed in the mutant, we were interested in possible cation imbalances in the mia mutants. To determine the elemental composition of the mutants, the total content of a range of elements in leaves from 5-wk-old wild-type and mia mutant plants was measured by inductively coupled plasma-mass spectrometry (ICP-MS). The ICP analysis showed that the content of all elements measured was

Table 1. Segregation of BASTA $A^{r}$ and BASTAs seedlings resulting from pollination of wild-type plants with pollen grains from mia heterozygous (mia-1/MIA or mia-2/MIA) plants

\begin{tabular}{|c|c|c|c|c|c|c|}
\hline \multirow[b]{2}{*}{ Experiment } & \multicolumn{3}{|c|}{ Wild-type $+\times$ mia-1/MIA ô } & \multicolumn{3}{|c|}{ Wild-type $+\times$ mia-2/MIA ô } \\
\hline & BASTA $^{r}$ & BASTA $^{\mathrm{s}}$ & $\begin{array}{l}\text { Transmission } \\
\text { efficiency }(\%)\end{array}$ & BASTA $^{r}$ & BASTA $^{\mathrm{s}}$ & $\begin{array}{l}\text { Transmission } \\
\text { efficiency }(\%)\end{array}$ \\
\hline 1 & 15 & 112 & 12 & 25 & 90 & 22 \\
\hline 2 & 23 & 96 & 19 & 22 & 78 & 22 \\
\hline 3 & 24 & 126 & 16 & 37 & 101 & 27 \\
\hline 4 & 18 & 124 & 13 & 22 & 108 & 17 \\
\hline 5 & 20 & 116 & 15 & 26 & 108 & 19 \\
\hline 6 & 26 & 107 & 20 & 34 & 120 & 22 \\
\hline Mean & 126 & 681 & 16 & 166 & 605 & 21 \\
\hline
\end{tabular}


Table 2. Genes with strongly decreased expression levels ${ }^{a}$ in mia insertion mutants

\begin{tabular}{|c|c|c|c|c|c|c|c|}
\hline $\begin{array}{l}\text { Rank } \\
\text { mia-2 }\end{array}$ & $\begin{array}{l}\text { Rank } \\
\text { mia-1 }\end{array}$ & $\begin{array}{c}\mathrm{FC} \\
\text { mia-2 }\end{array}$ & $\begin{array}{c}\mathrm{FC} \\
\text { mia-1 }\end{array}$ & $\begin{array}{c}\text { AGI } \\
\text { accession }\end{array}$ & $\begin{array}{l}\text { Gene } \\
\text { name }\end{array}$ & $\begin{array}{c}\text { Functional } \\
\text { category }^{\mathrm{b}}\end{array}$ & Gene annotation \\
\hline 1 & 1 & -162.7 & -177.3 & At5g23630 & MIA & TR & ATPase $E_{1}-E_{2}$ type family \\
\hline 2 & 2 & -157.6 & -118.3 & At2g15650 & & & copia-like retrotransposon family \\
\hline 3 & 5 & -138.5 & -58.1 & At4g39180 & & SEC & SEC14-like protein \\
\hline 4 & 18 & -89.8 & -36.8 & At2g41860 & & SIG & Calcium-dependent protein kinase, putative \\
\hline 5 & 3 & -86.3 & -67.3 & At3g05820 & & & beta-fructofuranosidase, putative \\
\hline 6 & 8 & -82.2 & -47.0 & At $\lg 51490$ & & & glycosyl hydrolase family 1 \\
\hline 7 & 15 & -67.2 & -37.8 & At $\lg 68610$ & & & hypothetical \\
\hline 8 & 6 & -65.2 & -56.8 & Atlg01460 & & SIG & phosphatidylinositol-4-phosphate 5-kinase family \\
\hline 9 & 12 & -58.6 & -40.6 & At2g35210 & & SEC & GLO3-like zinc finger \\
\hline 10 & 14 & -58.2 & -40.0 & At 1 g44160 & & $\mathrm{PF}$ & DNAJ chaperone C-terminal domain-containing \\
\hline 11 & 11 & -57.1 & -40.8 & At3g09530 & & SEC & exocyst subunit EXO70 family \\
\hline 12 & 9 & -56.6 & -43.3 & At5g61710 & & & hypothetical \\
\hline 13 & 17 & -55.7 & -37.4 & At4g15980 & & CW & pectinesterase family \\
\hline 14 & 16 & -54.5 & -37.8 & At3g03800 & SYP131 & SEC & syntaxin, putative \\
\hline 15 & 53 & -53.6 & -27.4 & At4g00350 & & TR & MATE efflux family \\
\hline 16 & 86 & -52.7 & -23.0 & At3g04630 & & & expressed \\
\hline 17 & 46 & -52.3 & -28.6 & At1g52240 & & & expressed \\
\hline 18 & 55 & -51.6 & -27.0 & Atlg61290 & SYP124 & SEC & syntaxin, putative \\
\hline 19 & 13 & -51.4 & -40.2 & At2g47340 & & CW & invertase/pectin methylesterase inhibitor family \\
\hline 20 & 26 & -50.9 & -32.4 & Atlg79860 & & & expressed \\
\hline 21 & 40 & -49.3 & -29.1 & At $\lg 75870$ & & & hypothetical \\
\hline 22 & 7 & -49.3 & -47.5 & At4g04980 & & $\mathrm{CW}$ & hydroxyproline-rich glycoprotein family \\
\hline 23 & 4 & -49.2 & -63.4 & At5g39310 & EXP24 & CW & expansin, putative \\
\hline 24 & 67 & -48.7 & -25.9 & At1g03920 & & SIG & protein kinase, putative \\
\hline 25 & 36 & -46.5 & -29.7 & At5g16100 & & & hypothetical \\
\hline 26 & 59 & -45.3 & -26.7 & At5g56640 & & & expressed \\
\hline 27 & 93 & -45.0 & -22.4 & At2g02720 & & $\mathrm{CW}$ & pectate lyase family \\
\hline 28 & 41 & -44.7 & -29.0 & At2g33100 & & CW & cellulose synthase family \\
\hline 29 & 68 & -44.4 & -25.2 & At4g12430 & TPPA & & trehalose-6-phosphate phosphatase, putative \\
\hline 30 & 50 & -42.9 & -27.8 & At5g27870 & & $\mathrm{CW}$ & pectinesterase family \\
\hline 31 & 19 & -42.6 & -36.0 & At5g41780 & & & myosin heavy chain-related \\
\hline 32 & 70 & -42.0 & -25.0 & At5g05070 & & & zinc finger (DHHC type) family \\
\hline 34 & 37 & -41.9 & -29.6 & At2g25600 & AKT6 & TR & potassium channel \\
\hline 35 & 34 & -41.6 & -30.5 & At5g51460 & & & trehalose-6-phosphate phosphatase \\
\hline 36 & 24 & -41.5 & -33.1 & At3g28150 & & & expressed \\
\hline 37 & 71 & -41.2 & -25.0 & At3g06830 & & $\mathrm{CW}$ & pectinesterase family \\
\hline 38 & 42 & -41.1 & -28.8 & At5g42490 & & SEC & kinesin motor family \\
\hline 39 & 99 & -41.0 & -21.7 & At3g52460 & & $\mathrm{CW}$ & hydroxyproline-rich glycoprotein family \\
\hline 40 & 27 & -40.9 & -32.3 & Atlg17540 & & SIG & protein kinase-related \\
\hline 41 & 75 & -40.7 & -24.4 & At1g04700 & & SIG & protein kinase family \\
\hline 42 & 33 & -40.6 & -30.6 & Atlg65240 & & & aspartyl protease family \\
\hline 43 & 56 & -40.6 & -27.0 & Atlg66210 & & & subtilase family \\
\hline 45 & 10 & -39.9 & -42.0 & At4g32630 & & & hypothetical \\
\hline 48 & 49 & -39.4 & -27.8 & Atlg69050 & & & expressed \\
\hline 49 & 22 & -38.3 & 34.2 & At3g60330 & AHA7 & TR & $\mathrm{H}^{+}$-ATPase, plasma membrane \\
\hline 50 & 20 & -37.7 & -35.7 & At3g01630 & & & nodulin-related \\
\hline
\end{tabular}

${ }^{a}$ For each mutant line genes were ranked according to wild-type expression level/mutant expression level. Genes are shown that featured in the top 50 of at least one list and in the top 100 of the other list. Ranks refer to the position in the mutant specific list of genes sorted by fold change (FC). (-) sign of the FC indicates down-regulation in the mutant.

${ }^{b}$ Functional categories (author designed): (TR) transport, (SIG) signaling, (SEC) secretory, (PF) protein folding, (CW) cell wall.

changed to various extents in the mutants (Table 4). The content of most elements including magnesium, calcium, manganese, iron, copper, zinc, and molybdenum was reduced, while the amount of boron and potassium was increased. Among the different elements analyzed, copper and molybdenum showed the most profound changes, each being present at $50 \%$ or less of the wildtype values (Table 4).

\section{Discussion}

Using Arabidopsis as a multicellular genetic model, we have identified loss-of-function mutations in a gene belonging to the small $\mathrm{P}_{5}$ subfamily of P-type ATPases that is ubiquitous in eukaryotic organisms. We show that the single $\mathrm{P}_{5}$ ATPase encoded by the plant genome plays a pivotal role in pollen development and male fertility. 
Table 3. Genes with strongly increased expression levels ${ }^{a}$ in mia insertion mutants

\begin{tabular}{|c|c|c|c|c|c|c|c|}
\hline $\begin{array}{l}\text { Rank } \\
\text { mia-2 }\end{array}$ & $\begin{array}{l}\text { Rank } \\
\text { mia-1 }\end{array}$ & $\begin{array}{l}\mathrm{FC} \\
\text { mia-2 }\end{array}$ & $\begin{array}{l}\mathrm{FC} \\
\text { mia-1 }\end{array}$ & $\begin{array}{c}\text { AGI } \\
\text { accession }\end{array}$ & $\begin{array}{l}\text { Gene } \\
\text { name }\end{array}$ & $\begin{array}{l}\text { Functional } \\
\text { category }^{\mathrm{b}}\end{array}$ & Gene annotation \\
\hline 1 & 1 & 190.9 & 163.2 & Atlg47980 & & & expressed \\
\hline 2 & 2 & 150.0 & 131.2 & At4g16480 & & TR & sugar transport family \\
\hline 3 & 3 & 123.8 & 119.6 & Atlg22760 & РАВРЗ & & polyadenylate-binding protein \\
\hline 4 & 6 & 113.2 & 74.8 & At2g28680 & & & cupin family \\
\hline 5 & 4 & 103.0 & 94.0 & At5g20710 & & & beta-galactosidase, putative lactase, putative \\
\hline 6 & 5 & 82.6 & 85.6 & At5g48570 & & $\mathrm{PF}$ & peptidyl-prolyl cis-trans isomerase, putative \\
\hline 7 & 7 & 74.3 & 54.2 & At4g08670 & & & protease inhibitor/seed storage/lipid transfer family \\
\hline 8 & 9 & 65.1 & 47.8 & At3g17630 & CHX19 & TR & cation/hydrogen exchanger, putative \\
\hline 9 & 10 & 64.4 & 44.6 & At2g16750 & & SIG & protein kinase family \\
\hline 10 & 8 & 51.1 & 51.1 & At1g80660 & AHA9 & TR & $\mathrm{H}^{+}$-ATPase, plasma membrane \\
\hline 11 & 11 & 48.4 & 40.3 & At5g03620 & & & subtilase family \\
\hline 12 & 23 & 42.4 & 17.1 & Atlg47400 & & & expressed \\
\hline 13 & 13 & 41.1 & 28.9 & Atlg18280 & & & protease inhibitor/seed storage/lipid transfer family \\
\hline 14 & 14 & 38.9 & 27.2 & At4g16160 & & & $\begin{array}{l}\text { mitochondrial import inner membrane translocase } \\
\text { subunit family }\end{array}$ \\
\hline 15 & 16 & 33.1 & 22.3 & At5g 40260 & & & nodulin MtN3 family \\
\hline 16 & 19 & 28.2 & 20.6 & At5g09500 & RPS15C & & 40S ribosomal protein S15 \\
\hline 17 & 15 & 26.9 & 25.0 & At3g05960 & & TR & sugar transporter, putative \\
\hline 18 & 18 & 26.2 & 21.3 & At2g32890 & & & hypothetical \\
\hline 19 & 24 & 25.1 & 16.4 & Atlg23730 & & & carbonic anhydrase, putative \\
\hline 20 & 17 & 25.0 & 22.1 & At4g10440 & & & dehydration-responsive family \\
\hline 21 & 22 & 24.1 & 17.1 & At3g 12580 & & $\mathrm{PF}$ & heat shock protien 70 , putative \\
\hline 22 & 25 & 23.9 & 16.0 & At4g16370 & & TR & oligopeptide transporter OPT family \\
\hline 23 & 46 & 22.4 & 9.0 & At5g52640 & HSP81-1 & $\mathrm{PF}$ & heat shock protein $81-1$ \\
\hline 24 & 27 & 22.4 & 14.7 & Atlg07340 & & TR & hexose transporter, putative \\
\hline 25 & 30 & 21.2 & 14.2 & At4g23680 & & & major latex protein-related \\
\hline 26 & 38 & 20.2 & 11.5 & At $\lg 50310$ & STP9 & TR & monosaccharide transporter \\
\hline 27 & 36 & 19.9 & 12.9 & At5g03250 & & & phototropic-responsive NPH3 family \\
\hline 28 & 26 & 19.0 & 14.9 & At3g19930 & STP4 & TR & sugar transporter \\
\hline 29 & 21 & 18.8 & 17.5 & At3g51490 & & $\mathrm{TR}$ & sugar transporter family \\
\hline 30 & 33 & 18.4 & 13.2 & At3g 15280 & & & expressed \\
\hline 31 & & 17.7 & & Atlg74310 & HSP101 & $\mathrm{PF}$ & heat shock protein 101 \\
\hline 32 & 32 & 17.2 & 13.3 & At 1 g24400 & & TR & lysine and histidine transporter, putative \\
\hline 33 & 34 & 17.1 & 13.1 & Atlg48470 & & & glutamine synthetase, putative \\
\hline 34 & 31 & 16.4 & 14.1 & At4g25950 & & TR & vacuolar ATP synthase, putative \\
\hline 35 & 20 & 16.3 & 17.7 & Atlg71680 & & TR & lysine and histidine transporter, putative \\
\hline 36 & 35 & 15.7 & 12.9 & At2g07560 & AHA6 & TR & $\mathrm{H}^{+}$-ATPase, plasma membrane \\
\hline 37 & 40 & 13.5 & 10.8 & At3g57330 & ACA11 & TR & $\mathrm{Ca}^{2+}$-ATPase, plasma membrane, putative \\
\hline 38 & 39 & 13.3 & 11.2 & At4g02140 & & & expressed protein \\
\hline 39 & 29 & 12.9 & 14.3 & At3g19090 & & & RNA-binding protein, putative \\
\hline 41 & 37 & 12.4 & 12.6 & Atlg10970 & ZIP4 & TR & metal transporter, putative \\
\hline 43 & 41 & 11.9 & 10.7 & At2g31360 & $A D S 2$ & & delta 9 desaturase \\
\hline 44 & 28 & 11.9 & 14.4 & At4g15210 & $B M Y 1$ & & beta-amylase/1,4-alpha-D-glucan maltohydrolase \\
\hline 45 & 51 & 11.4 & 8.0 & At2g25890 & & & glycine-rich protein/oleosin \\
\hline 46 & 45 & 10.8 & 9.4 & At3g21970 & & SIG & receptor-like protein kinase-related \\
\hline 47 & 50 & 10.8 & 8.4 & At4g19960 & KUP9 & TR & potassium transporter family \\
\hline 48 & 49 & 10.0 & 8.4 & At4g26830 & & $\mathrm{CW}$ & glycosyl hydrolase family 17 \\
\hline 49 & 64 & 9.9 & 6.6 & At2g33690 & & & - \\
\hline 55 & 42 & 8.7 & 10.7 & At3g17720 & & & glutamate decarboxylase putative \\
\hline 56 & 48 & 8.7 & 8.8 & At4g04460 & & & aspartyl protease family \\
\hline 84 & 12 & 5.5 & 36.9 & At2g29500 & $\begin{array}{l}h \operatorname{sp} 17 . \\
6 B-C I\end{array}$ & $\mathrm{PF}$ & 17.6 kDa class I heat shock protein \\
\hline 93 & 44 & 5.3 & 9.8 & At5g12030 & $\begin{array}{l}\text { hsp17. } \\
\text { 7-CII }\end{array}$ & $\mathrm{PF}$ & 17.7 kDa class II heat shock protein \\
\hline
\end{tabular}

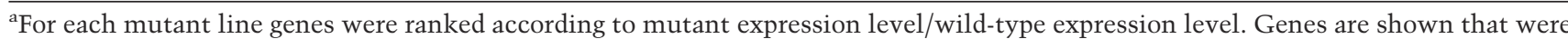
in the top 50 of at least one list and in the top 100 of the other list. Ranks refer to the position in the mutant specific list of genes sorted by fold change.

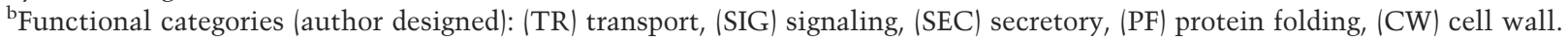


Table 4. Element analysis of leaves from wild-type and mia mutants

\begin{tabular}{|c|c|c|c|c|c|}
\hline \multirow[b]{2}{*}{ Mineral } & \multirow{2}{*}{$\begin{array}{l}\text { Wild } \\
\text { type } \mathrm{e}^{\mathrm{a}, \mathrm{b}}\end{array}$} & \multirow[b]{2}{*}{$\operatorname{mia}-1^{\mathrm{a}, \mathrm{b}}$} & \multirow[b]{2}{*}{$m i a-2^{a, b}$} & \multicolumn{2}{|c|}{$\begin{array}{l}\text { Mutant as \% } \\
\text { of wild type }\end{array}$} \\
\hline & & & & mia-1 & mia-2 \\
\hline B & 31.63 & 36.26 & 36.51 & 115 & 115 \\
\hline $\mathrm{Mg}$ & 6208 & 5099 & 5523 & 82 & 89 \\
\hline $\mathrm{Ca}$ & 52,426 & 35,046 & 39,088 & 67 & 75 \\
\hline $\mathrm{K}$ & 40,117 & 50,202 & 51,330 & 125 & 128 \\
\hline $\mathrm{Mn}$ & 150.72 & 111.50 & 115.51 & 74 & 77 \\
\hline $\mathrm{Fe}$ & 66.50 & 50.64 & 52.61 & 76 & 79 \\
\hline $\mathrm{Cu}$ & 5.03 & 2.54 & 2.34 & 50 & 47 \\
\hline $\mathrm{Zn}$ & 48.53 & 33.14 & 38.07 & 68 & 78 \\
\hline Mo & 5.95 & 2.36 & 2.71 & 40 & 46 \\
\hline
\end{tabular}

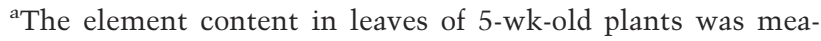
sured using ICP-MS.

bach value in the table is an average of four different measurements on 20 different plants. Values are given as parts per million.

${ }^{\mathrm{c}}$ Differences between wild-type and mia plants are significant at $P>0.05$ for all elements tested.

\section{MIA is important for pollen development} in Arabidopsis

The loss-of-function mutations in the MIA gene result in reduced fertility due to the formation of fragile, tetrad pollen and failure in pollen release. Only three other genes required for tetrad dissolution have so far been described in Arabidopsis. The quartet mutants-qrt1, qrt2, and qrt3-like mia, produce tetrad pollen grains with continuous exine bridges between the individual microspores of the tetrads (Preuss et al. 1994; Rhee et al. 2003). Formation of such fusion between the exines of individual microspores could result from defects in a number of processes prior to exine deposition. At the tetrad stage the microspores are embedded in the callosic wall and furthermore surrounded by the primary pollen mother cell wall, both of which have to be degraded in order for the microspores to be released (Stieglitz 1977; Rhee et al. 2003). Furthermore, failure in proper synthesis of the microspore wall, the so-called primexine, may lead to increased cell-cell adherence. The molecular identity and function of QRT1 and QRT2 genes has not yet been resolved, but $Q R T 3$ encodes a tapetum-specific polygalacturonase involved in the degradation of the pollen mother cell wall (Rhee et al. 2003). In the qrt1 and qrt2 mutants, the tetrad phenotype is associated with persistence of pectic polysaccharides between the microspores, which prevents the microspores separation and leads to tetrad formation (Rhee and Somerville 1998). In the mia mutants the expression of a high number of genes encoding cell wall proteins is reduced, and it is a likely explanation for the mutant phenotype that some of these genes are involved in tetrad dissolution. This idea is supported by the fact that an electron-dense substance, possibly representing pollen mother cell wall remnants, is present between the individual pollen grains of mia pollen tetrads. Of particular interest may be the reduced expression in mia mutants of pectin methylesterases, as members of this gene family have been shown to be involved in cell separation (Wen et al. 1999). The fact that the mutant pollen grains adhere to the anther locules and are not released at anthesis further suggests defects that increase cell-cell adherence.

A collapsed pollen phenotype has previously been observed in male sterile mutants of Arabidopsis (for review, see McCormick 2004). Pollen collapse can be caused by deletion of gametophytic gene functions (e.g., see Chen and McCormick 1996) or by disturbances in the somatic tapetal cell layer (e.g., see Zheng et al. 2003). In both quartet and mia mutants, the pollen phenotype is controlled by the parental genome, and not by the haploid gametophyte, as heterozygous $M I A / m i a$ and QRT/qrt plants do only produce morphologically normal pollen grains (Preuss et al. 1994; Rhee et al. 2003; this study). In contrast to the mia mutants, the individual pollen grains of the quartet tetrads are fully fertile and released from the anthers at maturity (Preuss et al. 1994; Rhee et al. 2003). The mia mutants display additional defects, suggesting that the gene has broader functions in male gametogenesis. These would include functions controlled by the gametophytic genome, as the probability of fertilization by mutant pollen grains is reduced.

\section{The mia mutant phenotype is linked to defects} in the secretory pathway

Several lines of evidence suggest that MIA interferes with secretory processes. First, MIA protein was localized to the ER and small, probably ER-derived secretory vesicles present in the vicinity of the both ER and the Golgi compartments. Localization of organelle proteins by isotope tagging likewise suggests that MIA protein localizes to the ER (T.P.J. Dunkley, P. Dupree, and K.S. Lilley, pers. comm.). In our study, the presence of MIA in microspores and tapetal cells was especially evident. These cell types are highy active in secretion (Murgia et al. 1991; Scott et al. 2004), which is in accordance with the fact that the strongest phenotype of our mia mutants is observed in the male reproductive tissues.

Second, we found that MIA could functionally complement a mutation in the yeast $\mathrm{P}_{5}$ ATPase gene, SPF1. Spflp has been localized to both the ER (Cronin et al. 2002; Vashist et al. 2002) and the cis-Golgi (Suzuki 2001). The protein functions in a variety of processes linked to protein processing such as N-glycosylation (Suzuki and Shimma 1999), control of hydroxyl-methylglutaryl-coenzyme A reductase 2 degradation /Cronin et al. 2000), and control of protein insertion orientation (Tipper and Harley 2002). Furthermore, the expression of SPF1 is up-regulated by the unfolded protein response (Travers et al. 2000), and spf1 is dependent on the activation of the unfolded protein response for viability $(\mathrm{Ng}$ et al. 2000; Vashist et al. 2002). Taken together, these results point to a role of SPF1 in protein biogenesis at early stages of the secretory pathway.

Third, a number of genes that in mia mutants exhibited high changes in expression represented genes in- 
volved in protein secretion. Transcript levels of a phosphatidylinositol-transfer protein SEC14 gene were markedly reduced in the mia mutants compared with wild type. Inactivation of the homolog SEC14 of S. cerevisiae blocks protein secretion at the level of the Golgi compartment (Bankaitis et al. 1989; Jouannic et al. 1998). Furthermore, members of the exocyst 70 protein family were also down-regulated at the transcriptional level (At3g09530, At2g28640, At5g13990, At5g13150). This is interesting, as the exocyst complex in yeast and mammals is required for targeting of vesicles to specific sites on the plasma membrane and is highly conserved among eukaryotes (Drubin and Nelson 1996; Boyd et al. 2004). Moreover, mutation of MIA caused down-regulation of a gene with high similarity to the GLO3 protein, which is involved in ER-Golgi retrograde vesicular transport in yeast (Poon et al. 1999) and of members of the syntaxin protein family that have been implicated in fusion of transport vesicles to target membranes (Sanderfoot et al. 2001).

Fourth, previous studies have shown that defects in the secretory machinery result in attenuated expression of a broad range of secreted proteins in both plants and yeast (Travers et al. 2000; Ng et al. 2000; Martinez and Chrispeels 2003) most probably to decrease protein input into the secretory pathway. Indeed, mia mutants exhibited reduced expression of a large number of genes encoding cell wall modifying enzymes. Structurally this was reflected by the presence of an electron-dense material between the baculae of the mutant pollen grain walls.

Finally, our results show that mutation of MIA results in imbalances in cellular cation homeostasis. The aberrant shape of mutant pollen grains and indications of plasmolysis as seen in electron micrographs also suggested that mutant pollen grains have difficulties maintaining turgor. The mia mutants differ significantly from wild-type plants with respect to mineral ion composition as revealed by mineral element analysis. This effect could be related to a general deficiency in the delivery of solute transporters to the plasma membrane.

Since MIA and Spflp belong to the P-type ATPase superfamily of ion transporters, it is likely that they influence protein biogenesis and transport through regulation of ion homeostasis in secretory pathway compartments. $\mathrm{A} \mathrm{Ca}^{2+}$ affinity of the $\mathrm{P}_{5}$ ATPases has previously been suggested (Cronin et al. 2002), and a number of genes involved in calcium biology including $\mathrm{Ca}^{2+}$ ATPases, calcium ion storage proteins, and calcium dependent signaling kinases exhibited significant changes in transcript levels in our expression profiling experiment. However, it is notable that none of the 10 amino acid residues involved in coordination of calcium binding in SERCA1 (Toyoshima et al. 2000) are conserved in the $\mathrm{P}_{5}$ ATPases MIA, Spflp and ATY2 (Fig. 1B). In P-type pumps, membrane-embedded charged and polar groups coordinate the bound cation. In the predicted membrane spanning segments of MIA, the only conserved charged residue pumps is the acidic Glu in the PPELP motif of transmembrane segment M4. In light of the low number of potential ion coordinating residues, it is difficult to envisage occlusion of a divalent cation in this pump, whereas models involving a coordination center for a monovalent cation cannot be excluded. An important avenue for future research will be to identify the substrate specificity of this new family of putative cation pumps.

In summary, this report represents the first description of a $\mathrm{P}_{5}$ ATPase in a multicellular organism. We have analyzed $\mathrm{P}_{5}$ ATPase function in Arabidopsis thaliana because this organism, in contrast to animals and fungi, only harbors one $\mathrm{P}_{5}$ ATPase gene. Thus, the problem of functional redundancy, which is common within the P-type ATPase family, could be avoided. Our data suggest that the $\mathrm{P}_{5}$ ATPases, by controlling the ionic status of secretory pathway compartments, regulate the proper trafficking of vesicle material to the plasma membrane. For plants, in particular, our results reveal an essential role of this family of ion pumps in pollen development.

\section{Materials and methods}

\section{Cloning of MIA $c D N A$}

The MIA cDNA was isolated by PCR amplification using the CD4-16 cDNA library of size-fractionated $(3-6 \mathrm{~kb})$ cDNAs as template. Primers were designed on the basis of the information in the P-type ATPase database (http://www.patbase.kvl.dk). All fragments were amplified using Dynazyme (Finnzymes) and cloned into the TA cloning vector 2.1-TOPO (Invitrogen) for sequencing.

\section{Arabidopsis knockout mutant isolation}

A. thaliana mutants were identified in the collections of the Arabidopsis knockout facility (http://www.biotech.wisc.edu/ Arabidopsis) by reverse genetics. We screened the 72,960 T-DNA mutagenized Arabidopsis ecotype Wassilewskija-2 lines of the BASTA collection with a combination of gene- and T-DNA LB-specific primers using the guidelines of the home page. Two gene-specific primers were designed on the basis of the sequence of genomic wild-type DNA /Oli 1027, 5' -TGAT CACCTGTTATCATCACCTGGAATCA-3'; and Oli 1030, 5'-CCTTTTGGGTTTCGCCGTGATTCGATCTT-3'). These primers were used with the T-DNA LB specific primer (JL202, 5'-CATTTTATAATAACGCTGCGGACATCTAC-3') in the screen. The T-DNA flanking regions were amplified by PCR, gel-purified, and cloned with the TA cloning vector 2.1-TOPO (Invitrogen). Sequencing of the flanking regions revealed the insertion site in the MIA gene.

\section{Plant growth}

Arabidopsis wild-type (WS-2) and mia mutant seeds were stratified in $0.2 \%$ agar for 3 nights at $4^{\circ} \mathrm{C}$. After sowing, the seeds pots were placed in a controlled growth chamber with short-day conditions ( $8 \mathrm{~h}$ light, $200 \mu \mathrm{mol} \mathrm{m} \mathrm{m}^{-2} \mathrm{sec}^{-1}, 70 \%$ humidity, $20^{\circ} \mathrm{C}$ ) in order to promote vegetative growth. After $3 \mathrm{wk}$, plants were transferred to long-day conditions (16 h light, $200 \mu \mathrm{mol} \mathrm{m} \mathrm{m}^{-2}$ $\sec ^{-1}, 70 \%$ humidity, $20^{\circ} \mathrm{C}$ ). For BASTA selection plants were grown on half strength Murashige and Skoog plates containing $50 \mu \mathrm{M}$ BASTA for $7 \mathrm{~d}$ with long-day conditions.

\section{Scanning and transmission electron microscopy}

Sepals and petals were removed from wild-type, mia-1, and mia-2 flowers prior to fixation in formalin-acetic acid-alcohol overnight. The flowers were dried in an Electron Microscopy Sciences 850 critical point dryer before being mounted on aluminum stubs with carbon paste. Samples were coated with 
gold-platinum using a Polaron SC7640 sputter coater (Fisions Instruments) and viewed in an Amray SEM 1830I under accelerating voltage of $20 \mathrm{kV}$. For transmission electron microscopy, stamens were fixed in $4 \%(\mathrm{w} / \mathrm{v})$ paraformaldehyde and $5 \%$ glutaraldehyde in $0.3 \mathrm{M}$ cacodylate buffer $(\mathrm{pH} 7.3)$ overnight, and then post-fixed in $1 \% \mathrm{OsO}_{4}(\mathrm{v} / \mathrm{v})$ for $1 \mathrm{~h}$. After dehydration with an acetone series, the stamens were embedded in Spurr's resin and cut in ultrathin sections, which were observed with a Philips CM100 microscope.

\section{Immunogold electron microscopy}

Anti-MIA rabbit polyclonal antibody was made against a synthetic peptide corresponding to amino acid residues 850-864. Synthetic peptide fused to ovalbumin was used for immunization of female rabbits. Preimmune serum was collected from the same rabbit. The sera were enriched for IgGs by ammonium sulfate precipitation.

To test the specificity of the anti-MIA antibody, $25 \mu \mathrm{g}$ of microsomal protein were separated by SDS-PAGE and electrotransferred to nitrocellulose. After blocking with $2 \%$ skimmed milk powder, the blot was probed with anti-MIA antibody (1: 3000) in TBS buffer overnight. After washing, the blot was incubated with a secondary anti-rabbit antibody coupled to alkaline phosphatase (1:5000) and developed according to the manufacturer's instructions (Promega, catalog no. S3771).

Stamens were fixed in $2 \%(\mathrm{w} / \mathrm{v})$ paraformaldehyde and $0.5 \%$ glutaraldehyde in $0.05 \mathrm{mM}$ phosphate buffer $(\mathrm{pH} 7.2)$. After abundant washing and 4 min post-fixation in $1 \% \mathrm{OsO}_{4}(\mathrm{v} / \mathrm{v})$, stamens were dehydrated with an ethanol series, embedded in London Resin White, and polymerized in gelatin capsules at $4^{\circ} \mathrm{C}$ under UV illumination.

The immunogold reaction on thin sections was performed according to Fleurat-Lessard et al. (1997). After hydration, etching, and saturation of nonspecific sites, sections were incubated overnight with anti-MIA antibody 1/50 diluted. After washing in PBS, these sections were placed for $40 \mathrm{~min}$ on TBS (pH 8.2), $0.2 \%(\mathrm{v} / \mathrm{v})$ Tween, $0.2 \%(\mathrm{v} / \mathrm{v})$ Triton X-100, $1 \%(\mathrm{w} / \mathrm{w}) \mathrm{BSA}$, and goat serum before a 2 -h application of a 15 -nm gold particlelabeled goat anti-rabbit IgG (Biocell) at a 1/50 dilution. In controls the anti-MIA antibody was saturated by the purified protein. After washing in TBS and contrast in uranyl acetate and lead citrate, the sections were observed with a Jeol (1010) microscope operated at $80 \mathrm{KV}$.

\section{Analysis of mia expression in T-DNA insertion mutants}

Total RNA was isolated from 2-wk-old leaves using the RNeasy Plant Mini Kit (Qiagen). Reverse transcription was carried out for $1 \mathrm{~h}$ at $42^{\circ} \mathrm{C}$ using M-MulV Reverse Transcriptase (New England Biolabs). Five microliters of the reverse transcription reaction were subsequently used as template in a PCR reaction with 30 (ACTIN) or 35 (MIA) cycles. Primers used were ACTIN: Oli 896, 5' -TGGAACTGGAATGGTTAAGGCTGG-3' and Oli 897; 5'-TCTCCAGAGTCGAGCACAATACCG-3'; MIA: Oli 1224, 5'-GGTTTTCTGTGTGGGTCTTTGGTGCTTGG-3' and Oli 1225, 5' -TTCACAATTAGACAAACCCCCGACTCCTC-3'. The primers used for MIA anneal on either side of the T-DNA insertions in both mia-1 and mia-2.

\section{Microarray experiments}

RNA isolated from wild-type and mia mutant anthers using the RNeasy Plant Mini Kit (Qiagen) and reverse transcribed into cDNA, in vitro transcribed into cRNA, labeled, and hybridized with Affymetrix ATH1 arrays according to the standard Affymetrix protocol (Affymetrix Inc.). This part of the work was carried out at the Sir Henry Wellcome Functional Genomics
Facility (SHWFGF), University of Glasgow. For image analysis we used Affymterix software resulting in nonnormalized raw data (.CEL files). Further data analysis was carried out through an automated analysis pipeline of the SHWFGF (http://www. gla.ac.uk/functionalgenomics). This procedure involves background correction, multichip normalization at the probe level, and conversion of the log-normalized probe level data into probe-set level data according to Robust Multichip Average (RMA) (Irizarry et al. 2003). After normalization pairwise comparison of data from all three chips was carried out and data were expressed at the gene level as fold-changes of expression levels in the two samples. It has been demonstrated that RMA low-level analysis results in lower fold-change values than those calculated from spiked RNA. The fold-changes given in Tables 2 and 3 are corrected for this difference according to Cope et al. (2004). iGA of the ranked lists was carried out as described before (Breitling et al. 2004). This procedure identifies subsets of genes with a common functional annotation, which, as a group, are differentially expressed. Only groups with $p$-values $<3 \times 10^{-4}$ were considered significant. Group assignment was based on Gene Ontology (http://www.geneontology. org) and TAIR (The Arabidopsis Information Resourse) gene families (http://www.arabidopsis.org).

\section{Digestion of plant material and ICP-MS analysis}

The plant material was lyophilized and homogenized in liquid $\mathrm{N}_{2}$. Five-microgram samples were predigested overnight with $750 \mu \mathrm{L}$ ultra-pure $\mathrm{HNO}_{3}$ (subboiled 69\% Baker Instra) in uncapped 6-mL PFTE bombs (Savillex Corporation). The PTFE bombs were capped and transferred to 50-mL PFA liners containing $7.5 \mathrm{~mL}$ ballast water and mounted in PEEK pressure jackets with self-sealing caps. Samples were digested and analyzed using ICP-MS equipped with an octopole reaction cell system (Agilent 7500c, Agilent Technologies). The analytical accuracy was checked by analyzing 5-mg samples of certified reference material (1515 apple leaf, National Institute of Technology). Only samples with accuracy better than $90 \%$ were used.

\section{Yeast strains and culture}

Plasmids pMP1780 (containing MIA) and pMP1786 (containing mia-D491N) under the control of a galactose promoter were expressed in yeast strains BY4741 (wild-type; Mat a his $3 \Delta 1$

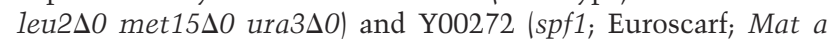

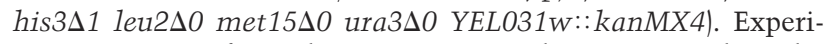
ments were performed at $30^{\circ} \mathrm{C}$ in synthetic minimal media supplemented with galactose $(2 \%)$, His $(3 \mathrm{mg} / \mathrm{mL})$, Met $(3 \mathrm{mg} /$ $\mathrm{mL})$ and Leu $(3 \mathrm{mg} / \mathrm{mL})$ with and without $200 \mu \mathrm{g} / \mathrm{mL}$ lovastatin.

\section{Acknowledgments}

We are grateful to José Bresciani and Ole B. Lyshede for excellent assistance with scanning electron microscopy. Microarray experiments were carried out in the SHW Functional Genomics Facility at the University of Glasgow with the help of Giorgia Riboldi-Tunicliffe and Pawel Herzyk.

\section{References}

Alonso, J.M., Stepanova, A.N., Leisse, T.J., Kim, C.J., Chen, H., Shinn, P., Stevenson, D.K., Zimmerman, J., Barajas, P., Cheuk, R., et al. 2003. Genome-wide insertional mutagenesis of Arabidopsis thaliana. Science 301: 653-657.

Arabidopsis Genome Initiative, The. 2000. Analysis of the genome sequence of the flowering plant Arabidopsis thaliana. Nature 408: 796-815.

Axelsen, K.B. and Palmgren, M.G. 1998. Evolution of substrate 
specificities in the P-type ATPase superfamily. J. Mol. Evol. 46: $84-101$.

- 2001. Inventory of the superfamily of P-type ion pumps in Arabidopsis. Plant Physiol. 126: 696-706.

Bankaitis, V.A., Malehorn, D.E., Emr, S.D., and Greene, R. 1989. The Saccharomyces cerevisiae SEC14 gene encodes a cytosolic factor that is required for transport of secretory proteins from the yeast Golgi complex. J. Cell. Biol. 108: 1271-1281.

Boyd, C., Hughes, T., Pypaert, M., and Novick, P. 2004. Vesicles carry most exocyst subunits to exocytic sites marked by the remaining two subunits, Sec3p and Exo70p. J. Cell. Biol. 167: 889-901.

Breitling, R., Amtmann, A., and Herzyk, P. 2004. Iterative Group Analysis (iGA): A simple tool to enhance sensitivity and facilitate interpretation of microarray experiments. BMC Bioinformatics 5: 34 .

Chen, Y.-C.S. and McCormick, S. 1996. sidecar pollen, an Arabidopsis thaliana male gametophytic mutant with aberrant cell divisions during pollen development. Development 122: 3243-3253.

Cope, L.M., Irizarry, R.A., Jaffee, H.A., Wu, Z., and Speed, T.P. 2004. A benchmark for Affymetrix GeneChip expression measures. Bioinformatics 20: 323-331.

Cronin, S.R., Khoury, A., Ferry, D.K., and Hampton, R.Y. 2000. Regulation of HMG-CoA reductase degradation requires the P-type ATPase Cod1p/Spflp. J. Cell Biol. 148: 915-924.

Cronin, S.R., Rao, R.J., and Hampton, R.Y. 2002. Cod1p/Spflp is a P-type ATPase involved in ER function and $\mathrm{Ca}^{2+}$ homeostasis. J. Cell Biol. 157: 1017-1028.

Drubin, D.G. and Nelson, W.J. 1996. Origins of cell polarity. Cell 84: 335-344.

Fleurat-Lessard, P., Bouche-Pillon, S., Leloup, C., and Bonnemain, J.L. 1997. Distribution and activity of the plasma membrane $\mathrm{H}^{+}$-ATPase in Mimosa pudica $\mathrm{L}$. in relation to ionic fluxes and leaf movements. Plant Physiol. 113: 747-754.

Honys, D. and Twell, D. 2003. Comparative analysis of the Arabidopsis pollen transcriptome. Plant Physiol. 132: 640-652.

Irizarry, R.A., Hobbs, B., Collin F., Beazer-Barclay, Y.D., Antonellis, K.J., Scherf, U., and Speed, T.P. 2003. Exploration, normalization and summaries of high density oligonucleotide array probe level data. Biostatistics 4: 249-264.

Jouannic, N., Lepetit, M., Vergnolle, C., Cantrel, C., Gardies, A.M., Kader, J.C., and Arondel, V. 1998. Isolation of a cDNA from Arabidopsis thaliana that complements the sec14 mutant of yeast. Eur. J. Biochem. 258: 402-410.

Krysan, P.J., Young, J.C., Jester, P.J., Monson, S., Copenhaver, G., Preuss, D., and Sussman, M.R. 2002. Characterization of T-DNA insertion sites in Arabidopsis thaliana and the implications for saturation mutagenesis. Omics 6: 163-174.

Lalanne, E. and Twell, D. 2002. Genetic control of male germ unit organization in Arabidopsis. Plant Physiol. 129: 865-875.

Martinez, I.M. and Chrispeels, M.J. 2003. Genomic analysis of the unfolded protein response in Arabidopsis shows its connection to important cellular processes. Plant Cell 15: 561-576.

McCormick, S. 2004. Control of male gametophyte development. Plant Cell 16: S142-S153.

Murgia, M., Charzynska, M., Rougier, M., and Cresti, M. 1991. Secretory tapetum of Brassica oleracea L.: Polarity and ultrastructural features. Sex. Plant Reprod. 4: 28-35.

Ng, D.T., Spear, E.D., and Walter, P. 2000. The unfolded protein response regulates multiple aspects of secretory and membrane protein biogenesis and endoplasmic reticulum quality control. J. Cell Biol. 150: 77-88.

Park, S.K., Howden, R., and Twell, D. 1998. The Arabidopsis thaliana gametophytic mutation gemini pollen1 disrupts microspore polarity, division asymmetry and pollen cell fate. Development 125: 3789-3799.

Poon, P.P., Cassel, D., Spang, A., Rotman, M., Pick, E., Singer, R.A., and Johnston, G.C. 1999. Retrograde transport from the yeast Golgi is mediated by two ARF GAP proteins with overlapping function. EMBO J. 18: 555-564.

Preuss, D., Rhee, S.Y., and Davis, R.W. 1994. Tetrad analysis possible in Arabidopsis with mutation of the quartet (Qrt) genes. Science 264: 1458-1460.

Procissi, A., De Laissardière, S., Fèrault, M., Vezon, D., Pelletier, G., and Bonhomme, S. 2001. Five gametophytic mutations affecting pollen development and pollen tube growth in Arabidopsis thaliana. Genetics 158: 1773-1783.

Rhee, S.Y. and Somerville, C.R. 1998. Tetrad pollen formation in quartet mutants of Arabidopsis thaliana is associated with persistence of pectic polysaccharides of the pollen mother cell wall. Plant J. 15: 79-88.

Rhee, S.Y., Osborne, E., Poindexter, P.D., and Somerville, C.R. 2003. Microspore separation in the quartet 3 mutants of Arabidopsis is impaired by a defect in a developmentally regulated polygalacturonase required for pollen mother cell wall degradation. Plant Physiol. 133: 1170-1180.

Sanderfoot, A.A., Pilgrim, M., Adam, L., and Raikhel, N.V. 2001. Disruption of individual members of Arabidopsis syntaxin gene families indicates each has essential functions. Plant Cell 13: 659-666.

Sari-Gorla, M., Gatti, E., Villa, M., and Pe, M.E. 1997. A multinucleate male-sterile mutant for maize with gametophytic expression. Sex. Plant Reprod. 10: 22-26.

Scott, J.R., Spielman, M., and Dickinson, H.G. 2004. Stamen structure and function. Plant Cell 16: S46-S60.

Smyth, D.R., Bowman, J.L., and Meyerowitz, E.M. 1990. Early flower development in Arabidopsis. Plant Cell 2: 755-767.

Stieglitz, H. 1977. Role of $\beta$-1,3-glucanase in post-meiotic microspore release. Dev. Biol. 57: 87-97.

Suzuki, C. 2001. Immunochemical and mutational analyses of P-type ATPase Spf1p involved in the yeast secretory pathway. Biosci. Biotechnol. Biochem. 65: 2405-2411.

Suzuki, C. and Shimma Y. 1999. P-type ATPase spf1 mutants show a novel resistance mechanism for the killer toxin SMKT. Mol. Microbiol. 32: 813-823.

Tipper, D.J. and Harley, C.A. 2002. Yeast genes controlling responses to topogenic signals in a model transmembrane protein. Mol. Biol. Cell 13: 1158-1174.

Toyoshima, C., Nakasako, M., Nomura, H., and Ogawa, H. 2000. Crystal structure of the calcium pump of sarcoplasmic reticulum at 2.6 angstrom resolution. Nature 405: 647-655.

Travers, K.J., Patil, C.K., Wodicka, L., Lockhart, D.J., Weissman, J.S., and Walter, P. 2000. Functional and genomic analyses reveal an essential coordination between the unfolded protein response and ER-associated degradation. Cell 101: 249-258.

Vashist, S., Frank, C.G., Jakob, C.A., and Ng, D.T.W. 2002. Two distinctly localized P-type ATPases collaborate to maintain organelle homeostasis required for glycoprotein processing and quality control. Mol. Biol. Cell 13: 3955-3966.

Weigel, D., Ahn, J.H., Blazquez, M.A., Borevitz, J.O., Christensen, S.K., Fankhauser, C., Ferrandiz, C., Kardailsky, I., Malancharuvil, E.J., Neff, M.M., et al. 2000. Activation tagging in Arabidopsis. Plant Physiol. 122: 1003-1013.

Wen, F., Zhu, Y., and Hawes, M.C. 1999. Effect on pectin methylesterase gene expression on pea root development. Plant Cell 11: 1129-1140.

Zheng, Z., Xia, Q., Dauk, M., Shen, W., Selvaraj, G., and Zou, J. 2003. Arabidopsis AtGPAT1, a member of the membranebound glycerol-3-phosphate acyltransferase gene family, is essential for tapetum differentiation and male fertility. Plant Cell 15: 1872-1887. 


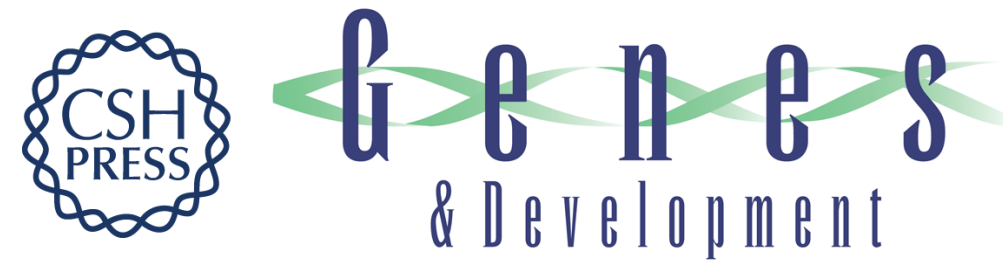

\section{Pollen development and fertilization in Arabidopsis is dependent on the MALE GAMETOGENESIS IMPAIRED ANTHERS gene encoding a Type V P-type ATPase}

Mia Kyed Jakobsen,, Lisbeth R. Poulsen,, Alexander Schulz,, et al.

Genes Dev. 2005, 19:

Access the most recent version at doi:10.1101/gad.357305

Supplemental Material

References

License

Email Alerting

Service
http://genesdev.cshlp.org/content/suppl/2005/10/27/19.22.2757.DC1

This article cites 42 articles, 26 of which can be accessed free at: http://genesdev.cshlp.org/content/19/22/2757.full.html\#ref-list-1

Receive free email alerts when new articles cite this article - sign up in the box at the top right corner of the article or click here.

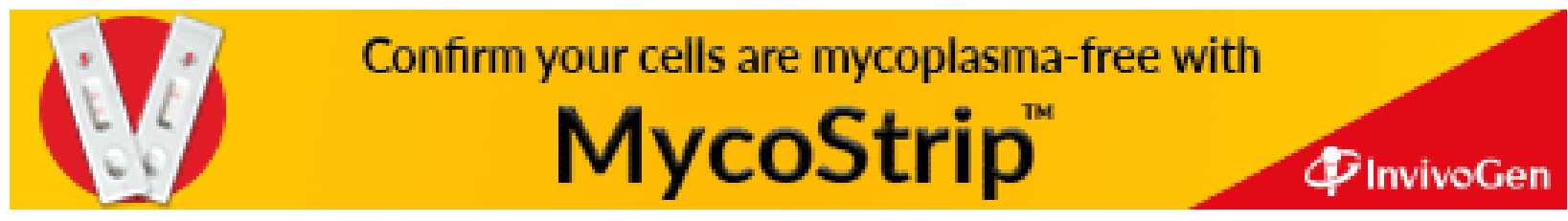

